\title{
Konsistensi Petunjuk Penggunaan Alat Peraga untuk Penentukan Luas Daerah Jajaran Genjang dan Luas Daerah Segitiga Bagi Siswa SD 6 Mataram
}

\author{
Ketut Sarjana $^{1 *}$, Endang P. Handayani², Siti Aminah², Nuraini ${ }^{2}$ \\ ${ }^{1}$ Program Studi Pendidikan Matematika, FKIP Universitas Mataram, Mataram, Indonesia. \\ 2 Sekolah Dasar Negeri 6 Mataram
}

DOI: $\underline{\text { https:// doi.org/10.29303/goescienceedu.v2i1.90 }}$

\section{Article Info}

Received : 5 Januari 2021

Revised : 20 Juni 2021

Accepted: 30 Juni 2021

\begin{abstract}
Abstrak: Tujuan penelitian ini untuk mengetahui konsistensi dan efektifitas petunjuk penggunaan alat peraga menentukan luas daerah jajaran genjang dan luas daerah segitiga bagi siswa SD 6 Mataram. Disadari bahwa penelitian dilakukan pada masa pandemi COVID 19, sehingga media didesain menjadi vedio pembelajaran yang menggambarkan penggunaaan alat peraga dan pedoman operasionalnya dinarasikan pada vedio tersebut. Berdasarkan hasil observasi dari 9 guru SD sebagai praktisi narasi dari pedoman operasional sangat tampak sesuai dengan petunjuk penggunaan alat peraga tersebut. Subyek penelitian ini adalah siswa SD kelas VI Mataram sebayak 3 kelas. Hasil evaluasi menunjukkan bahwa skor rata-rata yang diperoleh dari tiga pasang kelas tidak berbeda secara sigifikan pada taraf signifikansi $5 \%$ karena diperoleh $\left|t_{\hat{h}}\right|<t_{\text {tabel }}=2,0002$. Disisi lain ketuntasan yang diperoleh siswa di setiap kelas di setiap wilayah $>80 \%$. Ini berarti bahwa siswa tuntas dalam belajar tentang luas daerah Jajaran genakang dan luas daerah segitiga dengan $\mathrm{KKM}=70$. Disisi lain pesan yang disampaikan sama karena nilai rata-rata yang diperoleh siswa setiap kelas untuk masingmasing wilayah tidak berbeda secara signifikan. Dengan demikian penerapan petunjuk pengunaannya alat peraga menentukan rumus luas daerah Jajaran genjang dan luas daerah segitiga konsisten dan penggunaan alat peraga efektif bagi siswa SD 6 Mataram.
\end{abstract}

Kata kunci: Konsisten; Alat peraga; Petunjuk penggunaan; daerah jajaran genjang; segitiga

Abstract: The purpose of this study is to know the consistency and effectiveness of the instructions for the use of props to determine the area of the parallel ranks and the area of triangles for students of SD 6 Mataram. It is realized that the research was conducted during the COVID 19 pandemic, so that the media is designed to be a learning vedio that describes the use of props and operational guidelines narrated on the vedio. Based on the observations of 9 elementary school teachers as narrative practitioners of operational guidelines, it appears in accordance with the instructions for the use of such props. The subjects of this study were grade VI Mataram elementary school students as young as 3 grades. The evaluation results showed that the average score obtained from the three pairs of classes did not differ significantly at the level of significance of $5 \%$ because it was obtained $<$ ttabel $=2.0002$. On the other hand, the completion obtained by students in each class in each region $>80 \%$. This means that students are complete in learning about the area of genakang ranks and the area of triangle area with $\mathrm{KKM}=70$. On the other hand, the message is the same because the average score that each class gets for each region does not differ significantly. Thus the application of instructions for the use of props determines the formula of the area of the parallel range and the area of the triangle consistently and the use of effective props for students of SD 6 Mataram

Keywords: Consistent; Props; Instructions for use; genjang range area; triangle 


\section{Pendahuluan}

Sulitnya siswa sekolah dasar belajar geometri, karena materi geometri sangat abstrak sedangkan siswa sekolah dasar cara berpikirnya masih pada taraf operasi kongkret. Hal ini sejalan dengan apa yang diungkap oleh Piaget dalam Hudoyo menyebut bahwa siswa sekolah dasar berpikirnya masih pada taraf operasi kongkret (Hudoyo, 2008). Berkenaan dengan hal ini jika siswa sekolah dasar belajar geometri sebaiknya dihadapkan dengan obyek atau benda yang kongkrit yang cocok, benda dimanipulasi oleh anak untuk membangun konsep atau prinsip geometri yang sedang dipelajari. Hal ini sesuai dengan pernyataannya Brunner dalam Nyimas Aisyah menyebut bahwa dalam proses belajar anak sebaiknya diberi kesempatan memanipulasi benda-benda yang dirancang secara khusus dan dapat diotak atik oleh siswa di dalam memahami konsep matematika (Aisyah, 2007).

Siswa belajar memanfaatkan alat peraga akan banyak berbuat. Pandangan ini cocok dengan motto yang dikutip oleh Ruseffendi yang mengatakan bahwa Saya dengar maka saya lupa, Saya lihat maka saya tahu, Saya berbuat maka saya mengerti (Russefendi, 1996). Disisi lain juga dikemukakan oleh Brunner menyebut bahwa dalam tahap enaktif siswa secara langsung terlibat dalam memanipulasi obyek. Dari keteraturan obyek yang diamati siswa dapat mengabstraksi konsep dan prinsip yang dipelajari. Hal ini sesuai dengan pandangan kontruktivis adalah suatu pandangan yang menyatakan bahwa didalam belajar dan mengajar dimana peserta didik harus membangun sendiri arti dari pengalamannya dan interaksi dengan orang lain. Inilah sebagai alasan mengapa pengajaran matematika khususnya pengajaran geometri di SD memerlukan media peraga dan bantu. Dengan media ini siswa merasa senang, termotivasi, tertarik dan bersikap positif terhadap pengajaran matematika.

Sudah banyak tulisan yang menyebut bahwa penggunaan alat peraga dalam pembelajaran matematika menyebabkan pempelajaran menjadi efektif. Salah satu yang diungkap oleh Brown (1970) dalam Asra et al., (2007) menyebut bahwa media yang digunakan siswa atau guru dengan baik dapat mempengaruhi efektifitas proses belajar dan mengajar. Namun pernyataan itu belum menyebut bagaimana tata cara penggunaan media itu dapat dilakukan supaya sampai kepada tujuannya. Menggunakan alat peraga menentukan luas daerah jajaran genjang dan segitiga hasilnya berbeda satu dengan yang lainnya walaupun alat peraga yang digunakan sama untuk materi yang sama dan pada tingkatan yang sama. Ini berarti bahwa guru membutuhkan instrumen lain supaya pesan yang disampaikan sama. Itulah sebabnya diperlukan suatu petunjuk penggunaan alat peraga. Masalahnya sekarang adalah "Bagaimana konsistesi dan efektivitas petunjuk penggunaan alat peraga untuk menentukan luas daerah jajaran genjang dan daerah segitiga bagi siswa SD 6 Mataram?

Tujuan penelitian ini untuk mengetahui konsistensi dan efektifitas dari implementasi petunjuk penggunaan alat peraga menetukan luas daerah jajaran genjang dan luas daerah segitiga bagi siswa sekolah dasar di Kota Mataram.

Pemilihan muatan materi pelajaran yang tepat, yaitu yang dapat dipahami berdasarkan pengalaman kongkret siswa, maka alat peraga menjanjikan sebagai media dan sumber pembelajaran yang cocok bagi siswa SD. Melalui alat siswa dapat melihat secara langsung keteraturan yang ada, sehingga siswa lebih berhasil dalam belajarnya. Disisi lain melalui alat peraga siswa belajar melalui berbuat dan aktif belajar baik perorangan maupun berkelompok, karena alat peraga yang digunakan dapat dimanipulasikan dengan cara dikutak-katik seperti diraba, dipegang, dipindahkan atau dipasang dan dibongkar. Agar pemanfaatan alat peraga ini menjadi optimal, maka dalam mengoperasikannya diperlukan petunjuk penggunaannya. Menyangkut hal ini telah dilakukan penelitian tentang kontruksi alat peraga dan pedoman opersionalnya oleh Sarjana et al (2018) dengan hasil penelitian menyebutkan bahwa alat yang dikontruksi sangat valid. Jadi dapat dipahami bahwa siswa belajar dapat efektif bergantung pada sarana yang digunakan. Hal ini sejalan dengan Sudjana, (1992) prestasi belajar yang dicapai siswa dipengaruhi oleh faktor eksternal. Begitu pula Slameto (2003) prestasi belajar dipengaruhi oleh pemanfaatan media pembelajaran.

Setiap konsep abstrak dalam matematika yang baru dipahami anak perlu segera diberikan penguatan supaya mengendap, melekat dan tahan lama tertanam sehingga menjadi miliknya dalam pola pikir maupun pola tindaknya. Untuk keperluan inilah, maka diperlukan belajar melalui berbuat dan pengertian, tidak hanya sekedar hapalan atau mengingat-ingat fakta saja yang tentunya mudah dilupakan dan sulit untuk dapat dimiliki. Pandangan ini cocok dengan motto yang dikutip oleh Ruseffendi yang mengatakan bahwa saya dengar maka saya lupa, saya lihat maka saya tahu, saya buat maka saya mengerti (Russefendi, 1996).

Slogan saya lihat maka saya tahu mengisyaratkan kepada pendidik bahwa pada setiap proses pembelajaran matematika diharapkan memanfaatkan media yang dapat dilihat. Karena 
dengan cara melihat konsep abstrak geometri dapat dipahami dengan mudah. Selanjutnya saya berbuat dan saya mengerti membawa inspirasi bahwa di dalam kegiatan proses belajar matematika diharapkan siswa harus berbuat. Melalui cara berbuat siswa akan merasakan apa yang dipelajari bermakna bagi dirinya. Hal ini akan menjadi tenaga penggerak bagi siswa untuk mencari tahu tentang apa yang sedang dipelajari. Untuk itu media peraga yang digunakan untuk memperlancar proses sedianya yang berupa barang yang dapat dimanipulasikan yaitu dikutakkatik seperti diraba, dipegang, dipindahkan atau dibongkar pasang. Disisi lain alat bantu yang dimaksud adalah petunjuk penggunaan alat peraga alat peraga. Petunjuk penggunaan alat berfungsi menjelaskan cara melakukan bagaimana alat dapat digunakan yang para pemakainya belum seragam memahami. Inilah sebagai alasan mengapa pengajaran matematika khususnya pengajaran geometri di SD memerlukan alat peraga.

Dalam suatu pembelajaran keterampilan atau pengetahuan tertentu, strategi modelling adalah upaya untuk memberikan atau menyediakan model yang bisa ditiru sebelum siswa berlatih sendiri secara mandiri. Menurut Bandura, belajar yang dialami siswa adalah sebagian besar diperoleh dari suatu pemodelan, yaitu meniru perilaku dan pengalaman orang lain (Kardi, 2002). Model yang dimaksud biasanya berupa cara mengoperasikan sesuatu atau memberi contoh cara mengerjakan sesuatu, dan secara umum bagaimana cara mempelajari materi tertentu. Menyinggung pernyataan ini supaya alat peraga dapat digunakan dengan cara yang sama oleh setiap pemakainya pada topik yang sama diperlukan petunjuk penggunaan.

\section{Metode}

Dalam penelitian ini menerapkan alat bantu pembelajaran seperti alat peraga geometri tentang menentukan luas daerah Jajaran genjang, daerah segitiga, lengkap dengan pedoman operasional di kelas bagi siswa kelas VI SD 6 Mataram. Untuk mempermudah guru menggunakan media tersebut dibuatkan petunjuk penggunaannya.

Alat peraga dan petunjuk penggunaanya telah dibuat yang merupakan hasil penelitian yang dilakukan pada tahun 2018 Oleh Sarjana dkk. Hasil penelitian menunjukkan bahwa alat yang dikontruksi dan petunjuk penggunaannya telah layak dan valid. Kelayakan alat tersebut divalidasi oleh 9 orang yang terdiri dari 3 orang ahli dan 6 orang praktisi.

Sebagai Subyek Penelitian siswa kelas VI dimana pembelajaran menggunakan pembelajaran jaringan yaitu menggunakan WhatsApp karena penelitian dilakukan dimasa pandemic COVID 19 dan ke tiga kelas memiliki kemampuan yang hampir sama.

Dalam melaksanakan pembelajaran para guru dibantu dengan mendisain alat peraga tentang menentukan luas daerah bangun jajaran genjang dan segitiga dalam bentuk vedio pembelajaran. Mengenai pedoman operasaional dari alat peraga dinarasikan dalam vedio dan disesuaikan dengan petunjuk penggunaan alat peraga yang telah disusun.

Untuk memperoleh data tentang kepastian petunjuk penggunaan alat muncul dalam pembelajaran digunakan alat observasi. Uraian alat ini meliputi menggali prasyarat pengetahuan, menunjukkan unsur unsur dari bangun yang akan dicari luas daerahnya, melakukan percobaan memotong dan merangkai dan mencari hubungan unsur-unsur bangun datar untuk meyimpulakan rumus luas daerah yang dicarai. Tes digunakan untuk memeperoleh data tentang prestasi belajar siswa mengenai luas daerah jajaran genjang dan segitiga.

Teknik analisis data yang digunakan dalam penelitian adalah teknik deskriptip yaitu mencocokan pedoman opersional dengan narasi pada vedio dengan menggunakan sekala tidak tepat, kurang tepat dan tepat sangat tepat. Selanjutnya data mengenai hasil tes dianalis menggunakan uji t (Anton, 1990) yaitu:

$$
t=\frac{\overline{X_{1}}-\overline{X_{2}}}{\sqrt{\frac{\left(n_{1}-1\right) s_{1}^{2}+\left(n_{2}-1\right) s_{2}^{2}}{\left(n_{1}+n_{2}\right)-2}\left(\frac{1}{n_{1}}+\frac{1}{n_{2}}\right)}}
$$

karena sampel yang dibedakan terbatas dan taraf sigifikasi 0,05. Selanjutnya untuk mengetahui efektifitas pembelajaran menggunakan vedio digunakan uji ketuntasan yakni siswa dikatakan tuntas jika $80 \%$ lebih dari seluruh siswa memperoleh skor minimal sama dengan nilai ketuntantasan minimal (KKM)

\section{Hasil Dan Pembahasan}

\section{a. Hasil Penelitian.}

Sebelum implementasi dilaksanakan, dilakukan pemutaran vedio. Pemutaran vedio dimaksudkan untuk mencari imformasi tentang kecocokan antara narasi yang ada pada vedio dengan butir-butir dari pedoman opersional. Observasi vedio dilakukan oleh 9 guru SD senior yang masing-masing 3 guru dari 3 wilayah Cakranegara, Mataram dan Ampenen.

Data dari hasi observasi dari 9 guru SD setelah diolah menunjukkan bahwa petunjuk penggunaan alat peraga sangat tepat setelah dinarasikan di dalam vedio pembelajaran. Disisi lain data yang diperoleh dari hasil tes kemampuan siswa tentang luas daerah jajaran genjang dan luas daerah segitiga terlihat pada Tabel 1. 
Tabel 1. Hasil Uji t tiga pasang Kelas

\begin{tabular}{lllllll} 
& $A 1$ & $B 1$ & $A 1$ & $C 1$ & B1 & C1 \\
\hline Mean & 78,6129032 & 77,216666 & 78,6129 & 78,96875 & 77,21667 & 78,96875 \\
Variance & 111,5284946 & 91,56350575 & 111,5285 & 203,1925 & 91,56351 & 203,1925 \\
Observations & 31 & 30 & 31 & 32 & 30 & 32 \\
df & 59 & & 61 & & 60 & \\
t Stat & 0,541 & & $-0,1123$ & & $-0,56436$ & \\
T Critical two-tail & 2,0009953 & & 1,9996 & & 2,000298 & \\
\hline
\end{tabular}

Tabel 2. Rekap nilai t-hitung kelompok siswa SD 6 Mataram

\begin{tabular}{llll}
\hline No & Group & t-hitung & t-tabel \\
\hline 1 & A1 - B1 & 0,5406 & 2,0002 \\
2 & A1 - C1 & $-0,1123$ & \\
3 & B1 - C1 & $-0,5644$ & \\
\hline
\end{tabular}

\section{b. Pembahasan}

Belajar matematika berarti belajar tentang fakta, konsep prinsip dan operasi. Fakta meyangkut tentang postulat atau aksioma, konsep menyangkut tentang pengertian seperti definisi dan prinsip menyangkut tentang teorema, sifat, dalil ataupun rumus. Barang matematika ini adalah hal yang abstrak. Hal ini sesuai dengan apa yang diungkap oleh Hudoyo seperti pada uraian sebelumnya.

Dipahami bahwa siswa sekolah dasar berada pada taraf berpikir kongkrit. Sehingga jika pengajaran geometri seperti prinsip luas Jajaran genjang dan segitiga dipaksakan apa adanya jelas akan bermasalah. Akibatnya pengajaran matematika pada usia ini mengharuskan untuk memanfaatkan perantara, yang meyebabkan geometri dapat berkomunikasi dengan siswa sekolah dasar. Perantara disini adalah sebuah alat peraga yang di desain sedemikian rupa sehingga siswa dapat mengamati, meraba dan mencoba, menemukan selanjutnya menalar dalam rangka membangun prinsip-prinsip geometri. Prinsip geometri dalam penelitian ini menyangkut tentang rumus luas daerah daerah jajaran genjang dan luasdaerah segitiga. Alat peraga yang digunakan guru yang berbeda di dalam mempercepat proses pembelajaran dengan topik sama, belum tentu pesan yang disampaikan sama. Sehingga media peraga perlu didampingi dengan petunjuk penggunaan untuk menepis pernyataan tadi.

Pada penelitian ini mengimplentasikan alat peraga geometri untuk siswa kelas VI dilengkapi dengan petunjuk penggunaannya. Di atas telah diuraikan bahwa implementasi penelitian pada saat pandemic COVID 19 sehingga pilihan memodifikasi alat dengan vedio pembelajaran adalah pilihan yang paling jitu.

Implementasi alat peraga melalui vedio dilakukan oleh para guru dengan beberapa langkah seperti membagikan vedio, kemudian para siswa mengamati, mengerjakan tugas, klarifikasi dari guru, menyelesaikan latihan yang disetting dalam lembar kerja siswa, dan yang terakhir dilakukan tes. Dari hasil implementasi telah diperoleh hasil analisis data bahwa $\left|t_{t_{h}}\right|<t_{\text {tabel }}=2,0002$. Ini berarti bahwa pasangan kelompok nilai yang diperoleh skor rata-ratanya tidak berbeda secara signifikan pada taraf signifiknasi 0,05. Ini berarti bahwa tidak ada perbedaan prestasi yang meyakinkan. Jadi dengan menggunakan petunjuk penggunaan alat peraga tentang menentukan luas daerah jajarang dan luas daerah segitiga pesan yang disampaikan sama sehingga alat yang digunakan menjadi konsisten.

Disamping itu penggunaan alat peraga membuat pembelajaran efektif karena telah diperoleh ketuntasan belajar diatas $80 \%$. Hal ini bermakna bahwa $80 \%$ lebih dari seluruh siswa memperoleh skor minimal sama dengan KKM sebesar 70. Kuantitas ini mejelaskan bahwa telah terjadi perubahan prestasi belajar yang lebih baik. Ini berarti pembelajaran menjadi efektif. Hal ini sesuai yang disebut oleh Brown (1970) dalam Asra menyebut bahwa media yang digunakan siswa atau guru dengan baik dapat mempengaruhi efektifitas proses belajar dan mengajar.

Dari hasil tersebut menujukkan bahwa siswa belajar melalui alat peraga konsep abstrak bisa diamati oleh siswa melalui tayangan. Disisi lain melalui perintah yang ada siswa dapat berbuat melakukan kegiatan mencoba, tidak sekedar mengingat.

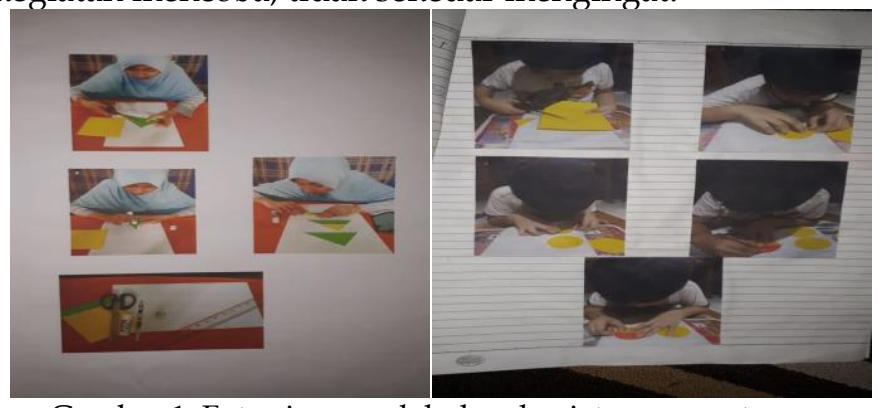

Gambar 1. Foto siswa melakukan kegiatan, memotong, mewarnai dan merankai

Penggunaan alat peraga dalam pembelajaran menyebabkan pempelajaran menjadi efektif. Salah satu 
yang diungkap oleh Brown (1970) dalam Asra menyebut bahwa media yang digunakan siswa atau guru dengan baik dapat mempengaruhi efektifitas proses belajar dan mengajar. Jadi hal ini sesuai dengan motto yang dikutif Ruseffendi yang menyatakan bahwa saya dengar maka saya lupa, saya lihat maka saya tahu, saya berbuat maka saya mengerti (Ruseffendi, 1992).

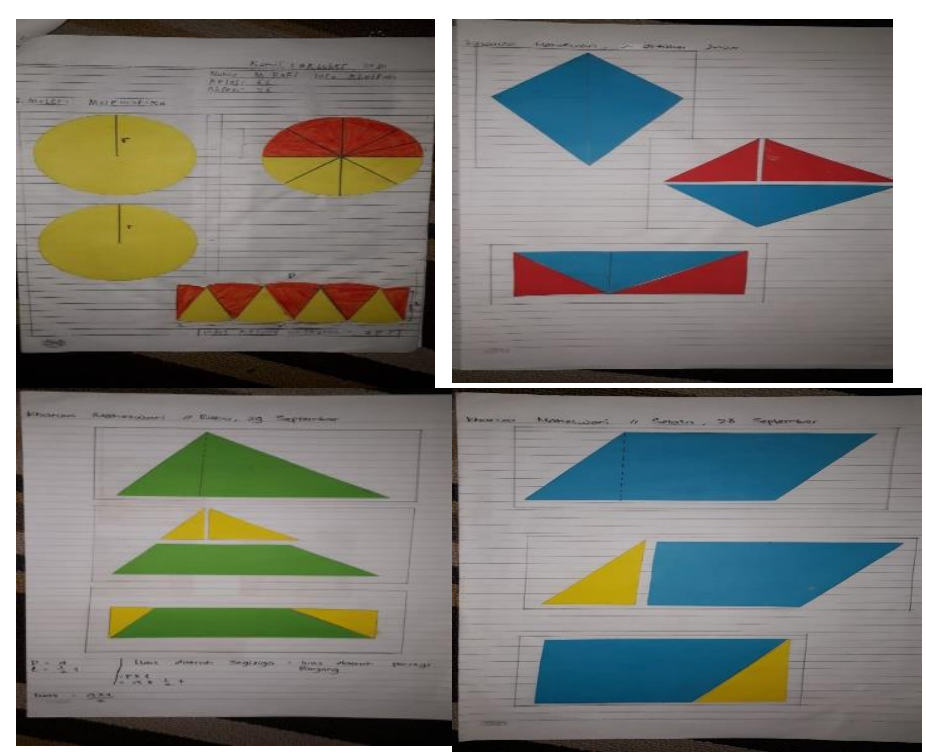

Gambar 2. Foto hasil melakukan percobaan : memotong, mewarnai dan merangkai

Slogan saya lihat maka saya tahu mengisyaratkan bahwa pada setiap proses pembelajaran matematika diharapkan memanfaatkan media yang dapat dilihat. Karena dengan cara melihat konsep abstrak geometri dapat dipahami dengan mudah. Selanjutnya saya berbuat dan saya mengerti membawa inspirasi bahwa di dalam kegiatan proses belajar matematika diharapkan siswa harus berbuat. Melalui cara berbuat siswa akan merasakan apa yang dipelajari bermakna bagi dirinya. Hal ini akan menjadi tenaga penggerak bagi siswa untuk mencari tahu tentang apa yang sedang dipelajari. Disisi lain alat peraga dengan petunjuk operasional, pemanfaatannya lebih optimal, karena petunjuk penggunaan alat itu berfungsi menjelaskan cara melakukan bagaimana alat dapat digunakan oleh para pemakainya yang belum seragam memahaminya.

Jadi secara keseluruhan penggunaan alat peraga yang dilengakpi dengan petunjuk penggunaannya menyebabkan pembelajaran menentukan rumus luas daerah jajaran genjang dan menentukan luas daerah segitiga menjadi konsiten dan efektif

\section{Kesimpulan}

Hasil penelitian menyimpulkan bahwa melalui penerapan alat peraga dalam pembelajaran mementukan rumus luas daerah jajaran genjang dan luas daerah segitiga menjadi efektif. Hal ini dapat diketahui dari ketuntasan yang dicapai untuk setiap kelas di Kota Mataram lebih dari $80 \%$. Dengan memnfaatkan petunjuk penggunaan alat pembelajaran menjadi konsisten karena telah diperoleh uji dua perbedaan nilai rata-rata tidak berbeda secara signifikan. Hal ini dapat diketahui $\left|t_{\text {hitung }}\right|<t_{\text {tabel }}=$ 2,0002. Jadi dengan menggunakan alat peraga dilengkapi petunjuk penggunaannya pembelajaran menjadi konsisten dan efektif.

\section{Daftar Pustaka}

Hudoyo, H. (2008). Pengembangan Kurikulum Matematika di depan Kelas, Usaha Nasional Surabaya.

Aisyah, N, dkk. (2007). Pengembangan Pembelajaran Matematika SD. Jakarta: Departemen Pendidikan Nasional.

Russefendi, E.T. (1996). Pendidikan Matematika III Modul 1-9, Depdikbud, Proyek Tenaga Kependidikan Jakarta.

Asra, A., Darmawan, D., Riana, C. (2007). Komputer dan Media Pembelajaran di SD. Dirjen Dikti Departemen Pendidikan Nasioanal. Jakarta.

Sarjana, K., Sridana, N., Turmuzi, M. (2018). Disain Media Peraga Dan Bantu Pembelajaran Geometri Bagi Siswa Sekolah Dasar Kelas Tinggi. Jurnal Ilmiah Profesi Pendidikan 3(2).

Sudjana, N. (1992). Dasar-Dasar Proses Belajar Mengajar. Bandung. Rosda Karya.

Slameto, S. (2003). Belajar dan Faktor-Faktor yang Mempengaruhinya. Jakarta. Renika Cipta.

Kardi, S., Momad, N. (2002). Pengajaran Langsung, Pusat Sains Matematika Sekolah Program Pasca Sarjana, Universitas Press.

Anton, D. (1990). Metode Statistik. Lembaga Penelitian dan Penerangan ekonomi dan social, Jln. S Parman. Jakarta Barat. 